Interdisciplinary Studies of Complex Systems

No. 15 (2019) 88-103

(C) Л. Гаврілова, Н. Воронова

https://doi.org/10.31392/iscs.2019.15.088

\title{
ЖУРНАЛИ З МУЗИЧНОГО МИСТЕЦТВА ТА ОСВІТИ В НАУКОМЕТРИЧНІЙ БАЗІ SCOPUS: НЕТНОГРАФІЧНИЙ АНАЛІЗ
}

\author{
Людмила Гаврілова ${ }^{1,2}$ Надія Воронова ${ }^{1,3}$
}

\begin{abstract}
Метою дослідження є проведення нетнографічного аналізу сайтів закордонних наукових журналів з музичного мистецтва та освіти, що входять до наукометричної бази Scopus, зробити класифікацію журналів за тематикою та виокремити видання з високими індексами цитування. Методологія дослідження грунтується на використанні нетнографічного аналізу як одного із специфічних методів онлайндосліджень, характерних для сучасної соціології, культурології, етнографії. Наукова новизна полягає у застосування нетнографії для аналізу сайтів наукових журналів з музичного мистецтва, виокремленні основних тематичних груп видань названої галузі, індексованих y Scopus.
\end{abstract}

Висновки. Нетнографічний аналіз дозволив виділити 5 груп: міждисциплінарні журнали, які досліджують музичне мистецтво в контексті естетики, культурології, філософії музики; журнали з музикознавства (проблеми історії, теорії музики, аналізу музичних творів, поліфонії, теорії жанрів, музичної стилістики тощо); видання, які висвітлюють окремі музичні напрями або періоди історії музики; журнали, присвячені застосуванню сучасних комп'ютерних (цифрових) технологій в музиці; видання з питань музичної освіти (навчання музики, розвиток музичних здібностей, виконавських умінь та ін.). Нетнографічний аналіз дозволив виділити найбільш цитовані журнали кожної групи. Сайти наукових видань було розглянуто не лише з боку проблематики, було визначено рік заснування журналу, країну, організацію-видавця, кількість збірників на рік, а також вивчено показники цитування, які зазвичай використовуються для оцінки публікацій в журналах гуманітарних галузей бази даних Scopus: Індекс цитування SJR та Iмпакт фактор SNIP. Авторами спростовано думку певної частини вітчизняної наукової спільноти щодо відсутності видань з музичного мистецтва та освіти в наукометричній базі даних Scopus.

Ключові слова: нетнографічний аналіз; наукометрична база Scopus; видання з музичного мистецтва та освіти; тематика досліджень.

\footnotetext{
1 ДВНЗ «Донбаський державний педагогічний університет».

2 havrilovalg@gmail.com, https://orcid.org//0000-0003-1814-5323.

3 voronova.ns@ukr.net, https://orcid.org//0000-0001-7957-1655.
} 


\title{
JOURNALS OF MUSICAL ART AND EDUCATION IN SCIENTOMETRIC DATABASE SCOPUS: NETNOGRAPHIC ANALYSIS
}

\author{
Liudmyla Havrilova, Nadiia Voronova
}

\begin{abstract}
The purpose of article is the netnographic analysis of sites of foreign scientific journals on musical art and education, which are included into scientometric database Scopus, as well as the classification of journals by subject and citation indexes. The methodology of the article is determined by a netnographic analysis as one of the specific methods of online researches that is typical for modern human sciences. Scientific novelty: the use of netnographic for the analysis of musical art scientific journals, the allocation of the main thematic groups of this industry magazines, indexed by Scopus.
\end{abstract}

Conclusions. It allocated five groups: interdisciplinary publications that study musical art in the context of ethics, culture studies, philosophy of music; journals of music studies (issues of history and theory of music, analysis of musical works, polyphony, theory of genres, musical stylistic etc.); the publications that highlight the different music styles or periods in music history; journals, devoted to implementing new computer (digital) technologies into music; publications on issues of musical education (the study of music; development of music and performance skills etc.). It is defined that most of publications on music issues in the scientometric database Scopus are devoted to music studies problems $(33,8 \%)$, studying different trends of musical art or certain historic periods of its development $(23,1 \%)$ and issues of music functioning in the context of culture studies, aesthetics and philosophy $(23,1 \%)$. Less attention is paid to teaching music, general and special musical education (12,3\% of publications), even fewer journals $(7,7 \%)$ are devoted to implementing modern computer (digital) technologies in music. The netnographic analysis gives an opportunity to single out the most cited journals in each group. The sites of scientific publications are considered from not only the point of view of their concerns, the year of foundation, a country, an institution of a publisher and a number of issues a year have been pointed out. Also citation indicators, which are usually used to assess the publications in journals of humanities database Scopus, were studied: index of citation SJR and impact factor SNIP. The authors have disproved the thoughts of a certain number of native scientists about the lack of publications on musical art and musical pedagogy in the scientometric database Scopus.

Keywords: netnographic analysis; Scopus scientometric database; publications on the musical art; publications on musical pedagogy; subjects of research.

Постановка проблеми. Обов'язковим показником наукової активності й продуктивності викладача вищого навчального закладу, у відповідності до Ліцензійних умов провадження освітньої діяльності закладів освіти (Постанова Кабінету Міністрів України «Про внесення змін до постанови Кабінету Міністрів України від 30 грудня 2015 р. № 1187», 2018), $\epsilon$ наявність наукових публікацій у періодичних виданнях, які включені до наукометричних баз, рекомендованих Міністерством освіти і науки України, зокрема Scopus або Web of Science Core Collection. До того ж наукові показники та загальний рейтинг вищого навчального закладу залежить 
від цитованості праць науково-педагогічних працівників вишу у цих базах. Присутність публікацій вітчизняних авторів у міжнародних наукометричних базах даних Scopus та Web of Science, як найвпливовіших і найавторитетніших, засвідчує рух української науки в європейський і світовий науково-дослідницький простір.

Актуальність публікації результатів наукових досліджень у виданнях баз даних Scopus та Web of Science в останні роки зросла, особливо для гуманітарних галузей, які довгі роки були замкнені у вітчизняному науковому просторі. Це було пов'язано з обмеженим користуванням іноземною (англійською) мовою, а також відсутністю вітчизняних видань з гуманітарних наук у вказаних наукометричних базах. Наразі ситуація поступово змінюється. До міжнародних авторитетних баз даних увійшли деякі українські видання з філософії, культурології, мистецтвознавства, педагогіки та інших гуманітарних наук. Серед них:

1) «Києво-Могилянський гуманітарний журнал» (Kyiv-Mohyla Humanities Journal, http://kmhj.ukma.edu.ua/) - видання Києво-Могилянської академії, тематика якого пов'язана з літературою, історією та філософією;

2) Вісник Національної академії керівних кадрів культури і мистецтв (National Academy of Managerial Staff of Culture and Arts Herald, http: //journals.uran.ua/visnyknakkkim), тематичні рубрики якого вміщують актуальні питання культурології та мистецтвознавства;

3) Науковий збірник «Новітня освіта» (Advanced Education) Національного технічного університету України «Київський політехнічний інститут» (http://ae.fl.kpi.ua/); проблематика збірника пов'язана з психолого-педагогічними, методологічними проблемами вищої освіти в Україні та світі; новітніми методами викладання гуманітарних і суспільних дисциплін у вищій школі; інформаційно-комунікаційними технологіями в освіті;

4) «Інформаційні технології і засоби навчання» (Information Technologies and Learning Tools, https://journal.iitta.gov.ua/) Національної академії педагогічних наук України - електронне наукове видання, присвячене проблемам використання інформаційно-комунікаційних технологій в системі освіти.

Серед названих видань лише Вісник Національної академії керівних кадрів культури і мистецтв висвітлює питання розвитку музичного мистецтва (в культурологічному й музикознавчому аспектах). Спеціалізованих журналів із проблем музичної освіти серед вітчизняних видань, індексованих y Scopus та Web of Science, поки що немає. Тож серед працівників вітчизняної мистецької освітньої галузі, побутує думка про тотальну відсутність наукових видань з музичного мистецтва та освіти, індексованих у міжнародних наукометричних базах Scopus та Web of Science, через що виникають проблеми з відповідністю науково-педагогічних працівників ЗВО ліцензійним вимогам. 3 даною позицією не можна погодитися, оскільки докладне вивчення загального переліку авторитетних міжнародних журналів, індексованих у Scopus, їх тематики та змісту засобами нетнографічного аналізу доводить інше. 
Аналіз останніх досліджень і публікацій. Нетнографія є одним із сучасних зарубіжних підходів до наукових досліджень в Інтернет-мережі. Це поняття увійшло до наукового обігу завдяки Р. Козинцю, який займається етнографічними й соціологічними дослідженнями в мережі, вивчає окремі веб-сайти, здобуває відповідну інформацію (R. Kozinets, 2010). Погоджуємося з А. Коломієць та Є. Громовим (2017), які вказують, що нетнографія стає популярним методом збирання й аналізу якісної інформації в Інтернет-спільнотах, поступово виходячи за межі етнографії, соціальної та культурної антропології, залучаючись до «цифрової гуманітарної педагогіки відкритої освіти» (В. Биков та М. Лещенко, 2016). Як влучно зазначає Р. Козинець $(2010,211)$, сутність нетнографії можна визначити як специфічний набір пов'язаних між собою дослідницьких практик зі збирання даних, їх аналізу й інтерпретації, а також етичних норм проведення такого типу досліджень.

Відзначимо загальне стрімке збільшення методів інтернет-досліджень, серед яких дослідники виокремлюють онлайн-методи (віртуальні, кіберметоди), цифрові та інструментально-сервісні методи (Е. Журавлева, 2013; П. Потапов, 2016). Нетнографія належить до першої групи, разом із такими методами інтернет-досліджень як «інтернет-інтерв'ю», «онлайн фокусгрупа» (чат, форум, опитування), мережевий аналіз соціальних мереж, блогів, форумів та ін.

Отже, нетнографія - це один із специфічних методів онлайн-досліджень, характерний для сучасних гуманітарних наук (соціології, етнографіï, культурології та ін.), нетнографічні методи разом із іншими методами інтернет-досліджень займають досить вагоме місце в методології гуманітарних наук. Для нашого дослідження нетнографія виявилася найбільш доцільним методом, оскільки всі журнали, індексовані у потужних наукометричних базах, розташовані в мережі, відкритий (чи навіть обмежений) доступ до них створює умови для докладного ознайомлення зі змістом та науковою проблематикою.

Оскільки аналізу журналів з музичного мистецтва та освіти, представлених у міжнародних наукометричних базах Scopus та Web of Science дотепер здійснено не було, вважаємо за доцільне провести нетнографічний аналіз сайтів журналів названих галузей, представлених у провідних виданнях світу, що входять до наукометричної бази Scopus, зробити класифікацію журналів за тематикою та виокремити видання з високими індексами цитування, що становить мету даної статті.

Виклад основного матеріалу. Аналіз тематики журналів, представлених у наукометричній базі Scopus, дозволяє відзначити, що станом на кінець 2017 року більше 110 наукових видань висвітлюють дослідження у галузі музичного мистецтва та музичної освіти. Це зовсім невеликий відсоток від загальної кількості наукових журналів у Scopus (36378), проте серед цих видань можна виокремити вагомі й відомі авторитетні джерела, які мають високі рейтинги й показники цитованості.

Усі журнали з музичного мистецтва та освіти, представлені у наукометричній базі Scopus, вважаємо за доцільне розділити на 5 груп, основним критерієм їх класифікації обрано тематику: 
1) Міждисциплінарні видання, які висвітлюють різні аспекти музичного мистецтва в контексті естетики, культурології, філософії музики.

2) Журнали музикознавчого змісту (історія, теорія музики, аналіз музичних творів, проблеми поліфонії, теорї жанрів, музичної стилістики тощо).

3) Журнали, присвячені окремим напрямам або періодам історії музичного мистецтва.

4) Видання з питань музичної освіти (навчання музики та її викладання, розвиток музичних здібностей та ін.).

5) Ж Жрнали, присвячені застосуванню сучасних комп'ютерних (цифрових) технологій в музиці.

Представимо наочно кількісне співвідношення видань з музичного мистецтва і освіти в наукометричній базі даних Scopus (рис.1).

Отже, більшість журналів музичної тематики наукометричної бази даних Scopus присвячені музикознавчим проблемам (різні аспекти аналізу музичних творів, теорії музики, гармонії, поліфонії тощо) (33,8\%), вивченню окремих напрямів музичного мистецтва або певних історичних періодів його розвитку $(23,1 \%)$ та питанням функціонування музики в контексті культурології, естетики, філософії $(23,1 \%)$. Значно менше уваги приділяється викладанню музики, розвитку музичних здібностей, загальній та спеціальній музичній освіті (12,3\% видань), ще менше журналів (7,7\%) присвячені застосуванню сучасних комп'ютерних (цифрових) технологій в музиці.

\section{Видання з музичного мистецтва і освіти в Scopus}

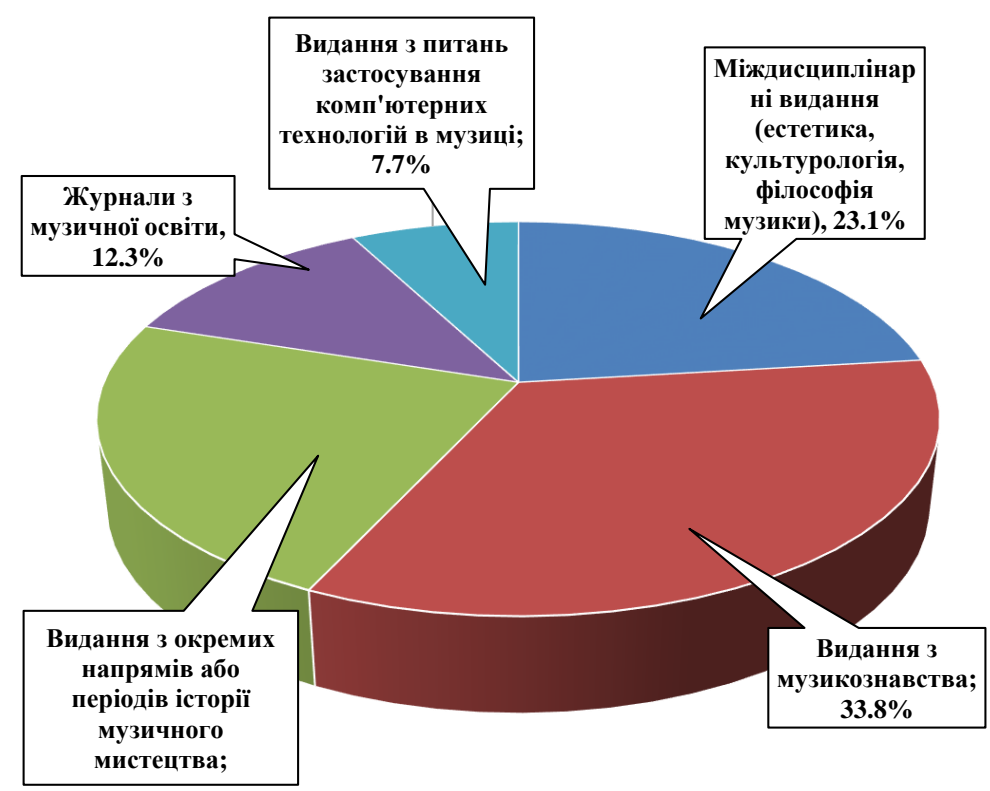

Рис. 1. Тематика журналів з музичного мистецтва та освіти в наукометричній базі Scopus 
Наступним етапом був нетнографічний аналіз журналів кожної тематичної трупи: було розглянуто сайти наукових видань з точки зору проблематики, визначено рік заснування журналу, країну, організацію-видавця, кількість збірників на рік, а також вивчено зміст випусків останніх років та показники цитування, які зазвичай використовуються для оцінки публікацій в журналах гуманітарних галузей бази даних Scopus:

1) Індекс цитування SJR - показник аналітичного порталу Scimago Journal \& Country Rank, який надає наукові показники по журналах і країнах. SJR розміщує рейтинги активності публікацій і статистику цитування журналів на основі інформації бази даних Scopus (Elsevier B.V); загалом SJR враховує декілька показників (загальна кількість опублікованих статей та їх цитувань, показники цитувань по роках, індекс Хірша), що засвідчує вплив і престижність наукових видань;

2) Імпакт фактор SNIP (Source Normalized Impact per Paper) - показник цитованості журналу, використовуваний базой даних Scopus; дозволяє безпосередньо порівнювати журнали різної тематики, зважаючи на частоту цитування авторами інших джерел, впливовість цитати та ін.; враховує рівень цитувань у кожній науковій галузі.

Проведений аналіз дозволив виокремити найбільш вагомі з точки зору рейтингу цитованості (за показниками SJR та SNIP) наукові журнали кожної тематичної групи (табл. $1-5$ ).

Як доводить аналіз, одним із найавторитетніших журналів, які висвітлюють проблеми розвитку музичного мистецтва в широкому культурологічному, соціологічному, музикознавчому та ін. контекстах, є видання європейського товариства когнітивної музичної науки Musicae Scientiae, ceредній показник цитування якого дорівнює 1,408 (IF SNIP) (рис.2). Серед останніх публікацій: дослідження впливу електронної танцювальної музики на рухи тіла, вивчення процесів відновлення емоційних станів під час слухання музики, огляд музично-теоретичної праці Л. Збіковського «Основи музичної граматики» та ін.

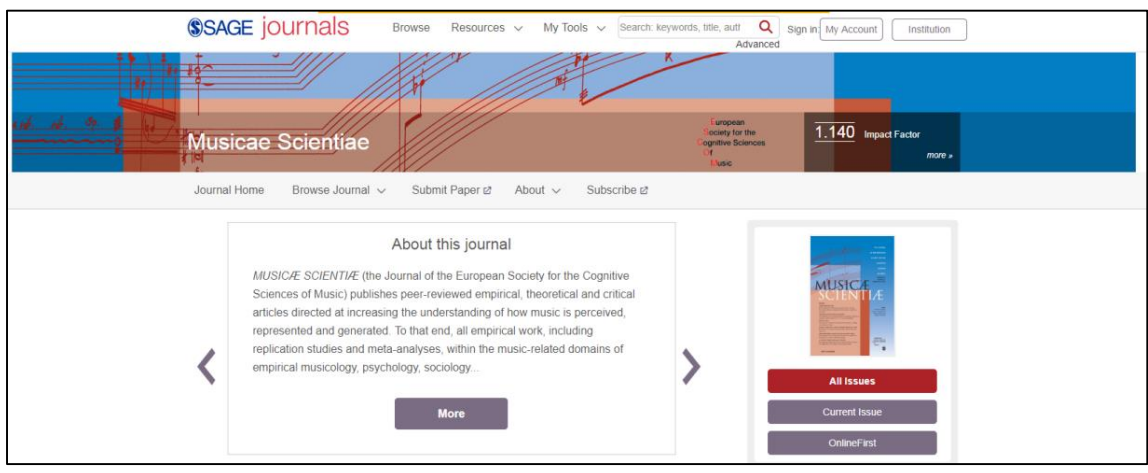

Рис. 2. Домашня сторінка журналу Musicae Scientiae (http://journals.sagepub.com/home/msx) 
Таблиця 1. Міждисциплінарні журнали

\begin{tabular}{|c|c|c|c|}
\hline \begin{tabular}{|c} 
Назва журналу, \\
е-адреса, рік заснування, \\
країна та видавник
\end{tabular} & Тематика журналу & \begin{tabular}{|c|} 
Індекс \\
цитува- \\
ння \\
SJR \\
(сере- \\
дній \\
пока- \\
зник \\
2014-- \\
2016 pp.)
\end{tabular} & \begin{tabular}{|c|} 
IF SNIP \\
(сере- \\
дній \\
пока- \\
зник \\
$2014-$ \\
2016 рр.)
\end{tabular} \\
\hline $\begin{array}{l}\text { International Journal of } \\
\text { Community } \\
\text { Music (Міжнародний } \\
\text { журнал музичної } \\
\text { спільноти), } \\
\text { http://www.ingentaconnect. } \\
\text { соm/content/1752-6299; } \\
\text { 2008; Великобританія; } \\
\text { Intellect Publishers }\end{array}$ & $\begin{array}{l}\text { Наукові статті, практичні диску- } \\
\text { сії, огляди, нотатки читачів та спе- } \\
\text { ціальні питання, що стосуються } \\
\text { усіх аспектів музичної спільноти } \\
\text { (виконавство, нотопис, вивчення } \\
\text { музичної спадщини, роль музики } \\
\text { в житті суспільства, соціологія му- } \\
\text { зики) }\end{array}$ & 0,231 & 0,582 \\
\hline $\begin{array}{c}\text { International Review of } \\
\text { the Aesthetics and } \\
\text { Sociology of Music } \\
\text { (Міжнародний журнал } \\
\text { з питань естетики та } \\
\text { соціології музики); } \\
\text { https://www.jstor.org/ } \\
\text { journal/intereviaestsoci; 1970; } \\
\text { Хорватія; Zagreb Academy of } \\
\text { Music } \\
\end{array}$ & $\begin{array}{l}\text { Проблеми музичної естетики, со- } \\
\text { ціології музики, соціальної історії } \\
\text { музики та історії ідей в музиці, } \\
\text { огляди, анонси, звіти конференцій }\end{array}$ & 0,132 & 0,620 \\
\hline $\begin{array}{l}\text { Journal of the American } \\
\text { Musicological Society } \\
\text { (Журнал американської } \\
\text { музикознавчої спілки); } \\
\text { http://jams.ucpress.edu/; } \\
\text { 1936; СШA; University of } \\
\text { California Press }\end{array}$ & $\begin{array}{l}\text { Широкий спектр досліджень му- } \\
\text { зичного мистецтва: історичне му- } \\
\text { зикознавство, музична критика, } \\
\text { аналіз музики, іконографія та ор- } \\
\text { ганологія, питання музичної педа- } \\
\text { гогіки, практики виконання, есте- } \\
\text { тики та герменевтики, етномузи- } \\
\text { кології, гендер і сексуальність, по- } \\
\text { пулярна музика та культурологія }\end{array}$ & 0,240 & 1,683 \\
\hline $\begin{array}{c}\text { Music Perception } \\
\text { (Музичне сприйняття); } \\
\text { http://mp.ucpress.edu/ } \\
\text { content/about; 1983; США; } \\
\text { University of California Press }\end{array}$ & $\begin{array}{l}\text { Дослідження у галузях музичної } \\
\text { психології, психофізики, лінгві- } \\
\text { стики, неврології, нейрофізіологї̈, } \\
\text { штучного інтелекту, комп'ютер- } \\
\text { них технологій, фізичної та архіте- } \\
\text { ктурної акустики та теорії музики }\end{array}$ & 0,878 & 1,213 \\
\hline $\begin{array}{c}\text { Musicae Scientiae } \\
\text { (Музична наука); } \\
\text { http://journals.sagepub.com/ } \\
\text { home/msx; 1997; European } \\
\text { Society for the Cognitive } \\
\text { Sciences of Music }\end{array}$ & $\begin{array}{l}\text { Емпіричні, теоретичні, критичні } \\
\text { дослідження у галузі емпіричного } \\
\text { музикознавства, психології, соціо- } \\
\text { логії, когнітивної науки, музичної } \\
\text { освіти, штучного інтелекту та тео- } \\
\text { рії музики }\end{array}$ & 0,588 & 1,408 \\
\hline
\end{tabular}


Таблиця 2. Журнали з музикознавства

\begin{tabular}{|c|c|c|c|}
\hline \begin{tabular}{|c} 
Назва журналу, \\
е-адреса, рік заснування, \\
країна та видавник
\end{tabular} & Тематика журналу & \begin{tabular}{|c|} 
Індекс \\
цитува- \\
ння \\
SJR \\
(сере- \\
дній \\
пока- \\
зник \\
$2014-$ \\
2016 рр.)
\end{tabular} & \begin{tabular}{|c|} 
IF \\
SNIP \\
(cере- \\
дній \\
пока- \\
зник \\
2014- \\
2016 pp.)
\end{tabular} \\
\hline $\begin{array}{c}\text { Journal of Music Theory } \\
\text { (Музично-теоретичний } \\
\text { журнал); https://read. } \\
\text { dukeupress.edu/journal-of- } \\
\text { music-theory/pages/About; } \\
\text { 1957; СШA; Yale University }\end{array}$ & $\begin{array}{l}\text { Дослідження в галузі аналізу та } \\
\text { глобальних історико-теоретичних } \\
\text { аспектів музики. ЖКурнал реалі- } \\
\text { зує структуралістський світогляд } \\
\text { і розглядає впливи філософії, ма- } \\
\text { тематики, інформатики, когнітив- } \\
\text { них наук та антропології на теорію } \\
\text { музики. }\end{array}$ & 0,196 & 0,825 \\
\hline $\begin{array}{c}\text { Journal of Musicological } \\
\text { Research (Журнал } \\
\text { музикознавчих досліджень); } \\
\text { https://www.tandfonline. } \\
\text { com/toc/gmur20/current; } \\
\text { 1979; США; University of } \\
\text { Northern Colorado }\end{array}$ & $\begin{array}{l}\text { Дослідження, що стосуються усіх } \\
\text { музикознавчих дисциплін: істори- } \\
\text { чна музикознавство, стиль та ре- } \\
\text { пертуарні дослідження, теорія му- } \\
\text { зики, етномузикологія, музична } \\
\text { освіта, органологія та міждисци- } \\
\text { плінарні музикознавчі досліджен- } \\
\text { ня. }\end{array}$ & 0,131 & 0,485 \\
\hline $\begin{array}{c}\text { Journal of New Music } \\
\text { Research (Журнал нових } \\
\text { музичних досліджень); } \\
\text { https://www.tandfonline. } \\
\text { com/toc/nnmr20/current; } \\
\text { Великобританія; 1972; } \\
\text { Таylor \& Francis }\end{array}$ & $\begin{array}{l}\text { Емпіричні музикознавчі міжди- } \\
\text { сциплінарні дослідження класи- } \\
\text { чної та сучасної музики: теорія му- } \\
\text { зики, комп'ютерна наука, музична } \\
\text { психологія, акустика, аналіз музи- } \\
\text { чних творів, композиція, музичні } \\
\text { інструменти. }\end{array}$ & 0,370 & 1,343 \\
\hline $\begin{array}{c}\text { Music Analysis (Аналіз } \\
\text { музики); https:// } \\
\text { onlinelibrary.wiley.com/page/ } \\
\text { journal/14682249/homepage/ } \\
\text { productinformation.html; } \\
\text { 1990; The Society for Music } \\
\text { Analysis and John Wiley \& } \\
\text { Sons Ltd }\end{array}$ & $\begin{array}{l}\text { Музично-аналітичні дослідження } \\
\text { від музики середньовіччя до по- } \\
\text { стмодерну, з характерним диску- } \\
\text { сійним аспектом, що привертає } \\
\text { увагу широкого кола читачів }\end{array}$ & 0,195 & 0,664 \\
\hline $\begin{array}{c}\text { Music Theory Spectrum } \\
\text { (Спектр теорії музики); } \\
\text { https://academic.oup.com/ } \\
\text { mts/pages/About; 1979; } \\
\text { Великобританія; Oxford } \\
\text { Асаdemic }\end{array}$ & $\begin{array}{l}\text { Статті з широкого кола тем у галу- } \\
\text { зі теорії та аналізу музики, вклю- } \\
\text { чаючи естетику, музичну критику } \\
\text { та герменевтику, історію музично- } \\
\text { теоретичних систем, посттональну } \\
\text { теорію, аналіз Шенкера, музичну } \\
\text { форму, ритм, музичне пізнання та } \\
\text { аналіз популярної музики. Схва- } \\
\text { люються дослідження на перехре- } \\
\text { сті музичної теорії та етномузико- } \\
\text { логії, математики, психології. }\end{array}$ & 0,196 & 1,244 \\
\hline
\end{tabular}


За індексом цитування SJR (Scimago Journal \& Country Rank) найвищий рейтинг серед видань з музичного мистецтва та освіти має американське видання Music Perception - журнал, який вивчає сприймання музики з точки зору психології, психофізики, лінгвістики, неврології, нейрофізіології, штучного інтелекту, акустики та інших наук (середній показник цитування SJR 0,878). Окремі випуски журналу розміщують матеріали у вільному доступі (на обмежений проміжок часу), наприклад спеціальні онлайн-випуски 2018 р. про перехресне модальне сприйняття музики, проблеми співвідношення, вимірювання та моделювання емоцій в музиці та ін. Видання Music Perception індексоване також у наукометричній базі Web of Science.

Серед журналів наукометричної бази Scopus музикознавчої тематики найбільш вагомим з точки зору показників цитованості (Індекс цитування SJR - 0,370; IF SNIP - 1,343) є англійське видання Journal of New Music Research, в якому з 1972 року висвітлюються результати досліджень практично всіх музикознавчих наук (теорія музики, музична акустика, аналіз музичних творів, композиція тощо) (рис.3). На сторінці журналу вказано його Impact Factor 2017 р., який дорівнює 0,979. Серед останніх матеріалів: проблеми створення музики з допомогою комп'ютера, її вплив на слухачів, застосування електронних засобів для навчання музики; вивчення мікротональної музики; аналіз авторських коментарів поліфонічних фортепіанних транскрипцій та ін.

Звернемо увагу також на журнал англійського Товариства теорії музики Music Theory Spectrum, тематика якого замкнена у вузько професійній музично-теоретичній галузі. Наприклад, в останньому номері журналу опубліковані дослідження тонально- гармонічних структур епохи Ренесансу і бароко, каденцій у музиці XVI століття, співвідношення темпів у симфонії Й. Брамса. Зустрічаються й роботи, присвячені проблемам музичної стилістики рок-музики (наприклад, вивчаються музичні образи та творчі «осяяння» Pink Floyd). Отже, коло музикознавчих проблем журналу Music Theory Spectrum є досить різноманітним і охоплює теоретичні аспекти музики всіх епох та стилів. Показники цитування (за Імпакт фактором SNIP) є досить високими $(1,244)$.

Ціла низка журналів з музичного мистецтва наукометричної бази Scopus висвітлюють музично-історичні дослідження окремих музичних напрямів, періодів історії музики та музичної творчості окремих країн світу. Серед них: American Music (https://www.press.uillinois.edu/journals/am.

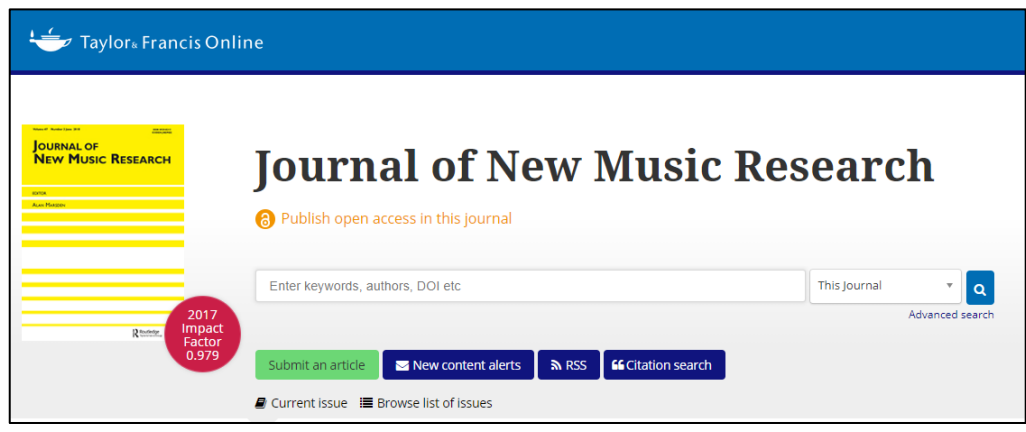

Рис. 3. Головна сторінка журналу Journal of New Music Research (https://www.tandfonline.com/toc/nnmr20/current) 
html) - щоквартальний журнал, присвячений всім аспектам американської музики та музики в Америці; Contemporary Music Review (http:// www.tandfonline.com/loi/gcmr20) - критичні огляди сучасної музики в усіх iï аспектах (виконання, композиція, тексти та контексти, естетика, технології та ін.); Nineteenth-Century Music Review (https://www.cambridge.org/ core/journals/nineteenth-century-music-review) - музичний огляд XIX століття в усіх аспектах культури; Folk Music Journal (https://www.jstor.org/ journal/folk-musij) - видання, що вміщує теоретичні й емпіричні дослідження в галузі етномузикології, танцювальної етнології та соціальної антропології, фольклористики та ін. Найвагоміші видання цієї тематичної групи наведені в таблиці 3.

В останні десятиліття до наукометричної бази Scopus увійшли журнали, присвячені використанню комп'ютерних технологій в музиці. Слід відзначити, що розвиток електронної музики, як такої, що пов'язана з використанням електронних засобів в музичній творчості, із електронним синтезом звуку, алгоритмічною композицією тощо, розпочався в середині $\mathrm{XX}$ століття й поступово виокремився у самостійний естетико-стильовий напрям. З'явилися й видання, які спеціалізувались на вивченні, усвідомленні, естетично-культурологічному й соціологічному обгрунтуванні жанрів і форм електронної (комп'ютерної) музики. Найстарішим і найбільш цитованим журналом, присвяченим дослідженням в галузі цифрових музичних технологій є американське видання Computer Music Journal (https: //www.mitpressjournals.org/cmj) (див. табл.4, рис.4), до редакційної колегії якого входять видатні комп'ютерні музиканти. Тематика журналу вміщує дослідження та розробки в галузі технологій, методів та естетики комп'ютерної музики, інтерв'ю з провідними композиторами - авторами електронних музичних творів, анонси нових аудіо- та MIDI-програм та апаратних засобів. Упродовж багатьох десятиліть Computer Music Journal залишається одним із провідних видань для всіх, хто займається електронною (комп'ютерною) музикою.

Douglas Keislar, Editor
Computer Music Journal is published quarterly with an annual sound and
video anthology containing curated music'. For four decades, it has been the
leading publication about computer music, concentrating fully on digital
sound technology and all musical applications of computers. This makes it
an essential resource for musicians, composers, scientists, engineers,
computer enthusiasts, and anyone exploring the wonders of computer-
generated sound.

Рис. 4. Головна сторінка Computer Music Journal 
Таблиця 3. Журнали з окремих музичних напрямів, музично-історичних періодів, музики окремих країн світу

\begin{tabular}{|c|c|c|c|}
\hline $\begin{array}{c}\text { Назва журналу, } \\
\text { е-адреса, рік заснування, } \\
\text { країна та видавник }\end{array}$ & Тематика журналу & \begin{tabular}{|c|} 
Індекс \\
цитува- \\
ння \\
SJR \\
(сере- \\
дній \\
пока- \\
зник \\
$2014-$ \\
2016 pp.)
\end{tabular} & $\begin{array}{c}\text { IF } \\
\text { SNIP } \\
\text { (cеpe- } \\
\text { дній } \\
\text { пока- } \\
\text { зник } \\
2014- \\
2016 \text { рp.)}\end{array}$ \\
\hline $\begin{array}{c}\text { Early Music History } \\
\text { (Історія давньої музики); } \\
\text { https://www.cambridge.org/ } \\
\text { core/journals/early-music- } \\
\text { history; 1996; } \\
\text { Великобританія; Cambridge } \\
\text { University Press }\end{array}$ & $\begin{array}{l}\text { Дослідження музики часів від } \\
\text { раннього середньовіччя до кінця } \\
\text { XVII століття; перевага надається } \\
\text { міждисциплінарним підходам та } \\
\text { розробкам нової методології; му- } \\
\text { зична критика, іконографія; про- } \\
\text { блеми музики і слова; музики і су- } \\
\text { спільства }\end{array}$ & 0,166 & 0,625 \\
\hline $\begin{array}{c}\text { Ethnomusicology } \\
\text { (Етномузикознавство); } \\
\text { http://www.ethnomusicology. } \\
\text { org/?Pub_JournalGI; 2002; } \\
\text { CWA; University of Illinois } \\
\text { Press on behalf of the Society } \\
\text { for Ethnomusicology }\end{array}$ & $\begin{array}{l}\text { Міжнародні дослідження в галу- } \\
\text { зі етномузикології: статті, кни- } \\
\text { ги, звукозаписи, фільми, відео та } \\
\text { мультимедійні додатки }\end{array}$ & 0,170 & 1,144 \\
\hline $\begin{array}{c}\text { Journal of the Society for } \\
\text { American Music (Журнал } \\
\text { Товариства американської } \\
\text { музики); } \\
\text { https://www.cambridge.org/ } \\
\text { core/journals/journal-of-the- } \\
\text { society-for-american-music; } \\
\text { 2007; Beликобританія; } \\
\text { Саmbridge }\end{array}$ & $\begin{array}{l}\text { Міжнародні дослідження різних } \\
\text { аспектів американської музики та } \\
\text { музики в Америці. Підтримуе- } \\
\text { ться проблематика, що виходить } \\
\text { за межі дисциплінарних стереоти- } \\
\text { пів: культурна ієрархія; соціаль- } \\
\text { ні, політичні, економічні, гендер- } \\
\text { ні та сексуальні проблеми; вплив } \\
\text { та роль засобів масової інформа- } \\
\text { ції; церковні, світські та популярні } \\
\text { контексти та традиції; історіогра- } \\
\text { фія та історія виконавства; аналіз, } \\
\text { критика та естетика музики. }\end{array}$ & 0,165 & 1,045 \\
\hline $\begin{array}{c}\text { Musical Quarterly } \\
\text { (Музичний квартал); } \\
\text { https://academic.oup.com/ } \\
\text { mq/pages/About; 1915; } \\
\text { Великобританія; Oxford } \\
\text { Асаdemic }\end{array}$ & $\begin{array}{l}\text { Дослідження американської музи- } \\
\text { ки в контексті культури ХХ столі- } \\
\text { ття; аналіз композиторської твор- } \\
\text { чості; дискусії з питань творчості, } \\
\text { текстів та рукописів; роздуми про } \\
\text { діячів музичного мистецтва; осо- } \\
\text { бисті заяви відомих виконавців та } \\
\text { композиторів; нариси про вистави } \\
\text { та записи музичних творів } \\
\end{array}$ & 0,134 & 0,714 \\
\hline $\begin{array}{c}\text { Popular Music (Популярна } \\
\text { музика); } \\
\text { https://www.cambridge.org/ } \\
\text { core/journals/popular-music; } \\
\text { 1981; Великобританія; } \\
\text { Cambridge University Press }\end{array}$ & $\begin{array}{l}\text { Міжнародні мультидисциплінарні } \\
\text { дослідження популярної музики } \\
\text { будь-якої історичної епохи та будь- } \\
\text { якого географічного розташуван- } \\
\text { ня (джаз, рок, реп та ін.) у різних } \\
\text { аспектах - від формування тото- } \\
\text { жності соціальної групи через по- } \\
\text { пулярну музику до роботи світової } \\
\text { музичної індустрії. }\end{array}$ & 0,188 & 0,986 \\
\hline
\end{tabular}


Таблиця 4. Журнали з питань застосування комп'ютерних технологій в музиці

\begin{tabular}{|c|c|c|c|}
\hline \begin{tabular}{|c} 
Назва журналу, \\
е-адреса, рік заснування, \\
країна та видавник
\end{tabular} & Тематика журналу & \begin{tabular}{|c|} 
Індекс \\
цитува- \\
ння \\
SJR \\
(сере- \\
дній \\
пока- \\
зник \\
$2014-$ \\
2016 рр.)
\end{tabular} & \begin{tabular}{|c|} 
IF \\
SNIP \\
(сере- \\
дній \\
пока- \\
зник \\
2014- \\
2016 pр.)
\end{tabular} \\
\hline $\begin{array}{c}\text { Leonardo Music Journal } \\
\text { (Музичний журнал } \\
\text { товариства Леонардо); } \\
\text { https://www.leonardo.info/ } \\
\text { Leonardo-Music-Journal; } \\
\text { 1991; Leonardo/The } \\
\text { International Society for the } \\
\text { Arts, Sciences and Technology }\end{array}$ & $\begin{array}{l}\text { Дослідження естетичних питань } \\
\text { сучасної музики, нових техноло- } \\
\text { гій та звукового мистецтва: імпро- } \\
\text { візацї̈, музичні спільноти, муль- } \\
\text { тимедійні вистави в цифрову епо- } \\
\text { ху музичного мистецтва. Перева- } \\
\text { га надається розвідкам впливу на- } \\
\text { уки і технологій на сучасне розумі- } \\
\text { ння звуку та музики, аналізу робо- } \\
\text { ти композиторів та звукорежисе- } \\
\text { рів, які розробляють нові мульти- } \\
\text { медійні арт-форми. У додатку до } \\
\text { кожного випуску - аудіо-вибірка } \\
\text { творів різних композиторів і вико- } \\
\text { навців та ноти. }\end{array}$ & 0,156 & 0,754 \\
\hline $\begin{array}{c}\text { Journal of Music, } \\
\text { Technology and } \\
\text { Education (ЈМTE, Музика, } \\
\text { технологія та освіта); } \\
\text { http://www.ingentaconnect. } \\
\text { com/content/intellect/jmte; } \\
\text { 2008; Великобританія; } \\
\text { Intellect Ltd. }\end{array}$ & $\begin{array}{l}\text { Журнал присвячений освітнім } \\
\text { аспектам музичної техніки та } \\
\text { технологічним аспектам музики. } \\
\text { Для педагогів, дослідників та пра- } \\
\text { ктиків, які тісно співпрацюють } \\
\text { з новими технологіями в галу- } \\
\text { зі музичної освіти та освітою } \\
\text { в галузі музичних технологій }\end{array}$ & 0,360 & 0,642 \\
\hline $\begin{array}{c}\text { Eurasip Journal on } \\
\text { Audio, Speech, and Music } \\
\text { Processing (Євразійський } \\
\text { журнал аудіо-, мовних та } \\
\text { музичних технологій); } \\
\text { https://asmp-eurasipjournals. } \\
\text { springeropen.com/about; } \\
\text { 2006; Німеччина; Springer }\end{array}$ & $\begin{array}{l}\text { Міждисциплінарний журнал для } \\
\text { поширення основних та прикла- } \\
\text { дних аспектів зв'язку мовлення } \\
\text { й музики та аудіопроцесів. До- } \\
\text { слідження вчених та інженерів, } \\
\text { які працюють над теорією та за- } \\
\text { стосуванням різних аудіосигналів, } \\
\text { з особливим упором на мову та му- } \\
\text { зику; мовна і аудіо-техніка; аналіз } \\
\text { мовлення, синтез, кодування; аку- } \\
\text { стика; отримання інформації про } \\
\text { музичний сигнал }\end{array}$ & 0,246 & 0,664 \\
\hline $\begin{array}{l}\text { Computer Music Journal } \\
\text { (ЖКурнал комп'ютерної } \\
\text { музики); https://www. } \\
\text { mitpressjournals.org/cmj; } \\
\text { 1977; СШA; MIT Press }\end{array}$ & $\begin{array}{l}\text { Дослідження комп'ютерної музи- } \\
\text { ки із щорічною відео- та аудіо ан- } \\
\text { тологією: цифрові звукові техно- } \\
\text { логії, музичні комп'ютерні дода- } \\
\text { тки; дослідження та розробки в га- } \\
\text { лузі технологій, методів та есте- } \\
\text { тики комп'ютерної музики; нові } \\
\text { аудіо- та MIDI-програми та апара- } \\
\text { тні засоби; інтерв'ю з провідними } \\
\text { композиторами цифрової музики. }\end{array}$ & 0,223 & 1,078 \\
\hline
\end{tabular}


Таблиця 5. Музично-освітні журнали

\begin{tabular}{|c|c|c|c|}
\hline $\begin{array}{c}\text { Назва журналу, } \\
\text { е-адреса, рік заснування, } \\
\text { країна та видавник }\end{array}$ & Тематика журналу & \begin{tabular}{c|} 
Індекс \\
цитува- \\
ння \\
SJR \\
(cеp. \\
пока- \\
зник \\
2014-- \\
2016 pp.)
\end{tabular} & \begin{tabular}{|c|} 
IF \\
SNIP \\
(cep. \\
пока- \\
зник \\
$2014-$ \\
2016 pp.)
\end{tabular} \\
\hline $\begin{array}{l}\text { British Journal of Music } \\
\text { Education (Англійський } \\
\text { журнал музичної освіти); } \\
\text { https://www.cambridge.org/ } \\
\text { core/journals/british-journal- } \\
\text { of-music-education; 1984; } \\
\text { Великобританія; Cambridge } \\
\text { University Press }\end{array}$ & $\begin{array}{l}\text { Сучасні дослідження музичної } \\
\text { освіти в усьому світі; формальне й } \\
\text { неформальне музичне викладання } \\
\text { та навчання; інструментальне та } \\
\text { вокальне виконавство, музика } \\
\text { у вищій школі, міжнародна порів- } \\
\text { няльна музична освіта, педагогічна } \\
\text { освіта. }\end{array}$ & 0,434 & 0,739 \\
\hline $\begin{array}{c}\text { International Journal of } \\
\text { Music Education } \\
\text { (Міжнародний журнал } \\
\text { музичної освіти); } \\
\text { http://journals.sagepub.com/ } \\
\text { home/ijm; 1996; International } \\
\text { Society for Music Education } \\
\text { (ISME) }\end{array}$ & $\begin{array}{l}\text { Рецензований журнал музично- } \\
\text { освітнього товариства (ISME) } \\
\text { публікує результати актуальних } \\
\text { емпіричних досліджень, музично- } \\
\text { освітні теорії, моделі, філософські } \\
\text { позиції навчання музики всіх } \\
\text { вікових груп. }\end{array}$ & 0,528 & 0,686 \\
\hline $\begin{array}{c}\text { Journal of Music Teacher } \\
\text { Education (Журнал освіти } \\
\text { вчителів музики); } \\
\text { http://journals.sagepub.com/ } \\
\text { home/jmt; 2011; США; } \\
\text { University of Colorado with } \\
\text { National Association for Music } \\
\text { Education }\end{array}$ & $\begin{array}{l}\text { Онлайн-журнал досліджень у га- } \\
\text { лузі викладання музики: філо- } \\
\text { софські, історичні, кількісні, які- } \\
\text { сні та змішані методи, пов'яза- } \\
\text { ні з музично-педагогічною освітою. } \\
\text { Перевага надається інноваційним } \\
\text { підходам у підготовці вчителів му- } \\
\text { зики }\end{array}$ & 0,390 & 0,802 \\
\hline $\begin{array}{c}\text { Journal of Research in } \\
\text { Music Education (Журнал } \\
\text { досліджень музичної освіти); } \\
\text { http://journals.sagepub.com/ } \\
\text { home/jrma; 2002; США; } \\
\text { National Association for Music } \\
\text { Education } \\
\end{array}$ & $\begin{array}{l}\text { Широкий спектр досліджень рі- } \\
\text { зних аспектів музичної педагогіки, } \\
\text { ¥ї історії та філософї̈, навчання } \\
\text { вокальної, інструментальної та за- } \\
\text { гальної музики на всіх рівнях, по- } \\
\text { чинаючи з раннього дитинства до } \\
\text { музичної освіти дорослих }\end{array}$ & 0,820 & 1,680 \\
\hline $\begin{array}{c}\text { Music Education Research } \\
\text { (Дослідження музичної } \\
\text { освіти); } \\
\text { https://www.tandfonline.com/ } \\
\text { action/journalInformation? } \\
\text { show=aimsScope\& } \\
\text { journalCode=cmue20; 1999; } \\
\text { Великобританія; Taylor \& } \\
\text { Francis }\end{array}$ & $\begin{array}{l}\text { Форум для обговорення результа- } \\
\text { тів, методів та методології музичної } \\
\text { освіти. Схвалюються якісні та кіль- } \\
\text { кісні методи дослідження, етногра- } \\
\text { фічні, дослідницькі та експеримен- } \\
\text { тальні підходи, викладання музики } \\
\text { поза межами європейської «класи- } \\
\text { чної» традиції, міждисциплінарні } \\
\text { дослідження музичної освіти в кон- } \\
\text { тексті соціології, гендеру, культу- } \\
\text { ри, етнічності, інклюзивної освіти } \\
\text { тощо. }\end{array}$ & 0,621 & 0,962 \\
\hline $\begin{array}{c}\text { Research Studies in Music } \\
\text { Education } \\
\text { (Музично-педагогічні студіï); } \\
\text { http://journals.sagepub.com/ } \\
\text { home/rsma; 1993; Австралія; } \\
\text { Association with Society for } \\
\text { Education, Music and } \\
\text { Psychology Research }\end{array}$ & $\begin{array}{l}\text { Дослідження у галузі музичної } \\
\text { освіти з увагою до розроблення ме- } \\
\text { тодології та її застосування до рі- } \\
\text { зноманітних проблем теорії і пра- } \\
\text { ктики музичної освіти. }\end{array}$ & 0,615 & 0,767 \\
\hline
\end{tabular}


Окрему групу видань наукометричної бази Scopus складають журнали, присвячені методам та методології музичної освіти. Серед інших видань музичної тематики вони мають чітку наукову орієнтацію на дослідження питань навчання музики: різні аспекти музичної педагогіки розглядаються і в широкому контексті філософських, історичних, етнографічних пошуків, і з точки зору інновацій в музичній освіті, і з боку виконавської майстерності (інструментальної та вокальної), вивчення музично-освітніх теорій, заглиблення у сферу музикотерапії в системі терапії мистецтвом, пошуку нововведень у формальній й неформальній музичній освіті. Переважна більшість журналів означеної тематики видаються в Америці й Великобританії, мають статус міжнародних видань, оскільки зазвичай підтримуються товариствами та асоціаціями музичної освіти різних країн світу. Найбільш авторитетні й вагомі музично-освітні видання наукометричної бази даних Scopus наведені у таблиці 5 .

Слід звернути увагу дослідників, яких цікавлять проблеми музичнопедагогічної освіти, на Journal of Research in Music Education (http://journals.sagepub.com/home/jrma), що був започаткований у 2002 p. Національною асоціацією музичної освіти США. Журнал має найвищі показники цитування серед аналогічних часописів (за показниками наукометричної бази Scopus: середній показник Індексу цитування SJR - 0,820; Імпакт фактор SNIP - 1,680). Перегляд останніх номерів журналу, аналіз тематики статей, кількісних показників (переглядів, завантажень, цитувань) доводить, що видання оприлюднює широко коло наукових пошуків сучасних вчених у галузі музичної педагогіки, орієнтованих перш за все на емпіричні дослідження. Серед музично-освітніх проблем, що висвітлюються на сторінках журналу в 2018 році: вивчення впливу медитації та перфекціонізму на почуття тривожності студентів музичних коледжів; реалізація проекту «Музична культура початкової школи» у формуванні мультикультурної чутливості дітей; вивчення змісту та стандартів якості оцінювання сольного інструментального виконавства; дослідження процесів упізнавання дорослими слухачами мелодії при гармонійних деформаціях; саморегуляція в музичній практиці: мікроаналіз як техніка збору даних для педагогічного втручання. Найбільший інтерес серед читачів та відповідний високий рейтинг (за даними від 2016 року, наведеними в журналі) мають статті про специфіку взаємовідносин у молодіжному оркестрі (Marching Band) та про вплив здатності до співу на прогнозування рішень студентів щодо участі у факультативному навчанні музики в початкових школах.

\section{Висновки}

Нетнографічний аналіз наукових журналів з музичного мистецтва та освіти, індексованих у наукометричній базі даних Scopus, дозволяє зробити певні висновки:

1) Тематичний спектр журналів, які в тому чи іншому аспекті торкаються проблем музичного мистецтва, досить широкий: від мультидисциплінарних теоретичних проблем функціонування музики в контексті культурології, соціології, філософії, етнографії та інших наук до специфічних музикознавчих історико-аналітичних нарисів та есе. 
2) В останні роки до аналізованої групи входить все більше видань, пов'язаних із використанням комп'ютерних технологій в музиці та музичній освіті.

3) Ж Жрнали з музичної педагогіки орієнтовані передусім на висвітлення конкретних емпіричних результатів наукових досліджень.

Отже, не зважаючи на відсутність спеціалізованих вітчизняних журналів з музичного мистецтва і освіти, індексованих у наукометричних базах Scopus та Web of Science, українські науковці - представники музичної галузі мають можливість оприлюднити результати власних наукових пошуків у численних зарубіжних виданнях, обираючи журнал відповідної тематичної спрямованості: міждисциплінарне видання, присвячене розвитку музики в контексті інших наук, журнал із того чи іншого напряму музикознавства, з питань музичної освіти чи проблем застосування комп'ютерних технологій в музиці.

Напрями подальших досліджень вбачаємо в аналогічному аналізі журналів з музичного мистецтва та освіти, індексованих у наукометричній базі Web of Science, вивчення специфіки їх тематичного спектру та показників цитованості.

\section{Література}

[1] Kozinetz V. R. Netnography: Doing Ethnographic Research Online. London: Sage Publications Ltd, 2010. https://www.amazon.com/Netnography-Doing-Ethnographic-Research-Online/dp/1848606451.

[2] Биков В. та Лещенко М. Цифрова гуманістична педагогіка відкритої освіти. Теорія $i$ практика управління соціалъними системами 4(2016):115-130. http://nbuv.gov.ua/UJRN/Tipuss_2016_4_13.

[3] Журавлева Е. Ю. К типологии методов интернет-исследования. Вопросы философии, 5(2013):84-93. https://www.researchgate.net/publication $/ 264673423$.

[4] Коломієць А. М. та Громов Є. В. Нетнографічний аналіз тематичного спектру педагогічних досліджень у виданнях з наукометричної бази Scopus. Інформаційні технологї $і$ засоби навчання 59(2017):179-188. https://journal.iitta.gov.ua/index.php/itlt/article/view/1666.

[5] Потапов П. Г. Проблемы современной методологии: методы интернетисследований. В Высшее образование в России и Беларуси в контексте Болонского процесса, 308-311. Гомель: ГГТУ им. П. О. Сухого, 2016. https://elib.gstu.by/bitstream/handle/220612/14549.

[6] Про внесення змін до постанови Кабінету Міністрів України від 30 грудня 2015 р. №1187. Постанова Кабінету Міністрів України віd 10.05.2018 p. № 347. http://zakon.rada.gov.ua/laws/show/347-2018$\% \mathrm{D} 0 \% \mathrm{BF}$.

\section{References}

[1] Kozinetz, V. R. Netnography: Doing Ethnographic Research Online. London, UK: Sage Publications Ltd., 2010. https://www.amazon.com/Netnography-Doing-Ethnographic-Research-Online/dp/1848606451. 
[2] Bykov, V.\& Leshchenko, M. Digital humanistic pedagogy of open education. Teoriia i praktyka upravlinnia sotsialnymy systemamy, 4 (2016): 115130. http://nbuv.gov.ua/UJRN/Tipuss_2016_4_13.

[3] Zhuravleva, E. Ju. To the typology of Internet research methods. Voprosy filosofii, 5 (2013): 84-93. https://www.researchgate.net/publication/ 264673423.

[4] Kolomiets, A. \& Gromov, Y. Netnographic Analysis of Pedagogical Investigations Subject Spectrum of Periodical Journals Which are Indexed in Scopus Scientometric Database. Informatsiini tekhnolohii $i$ zasoby navchannia, 59 (2017): 179-188. https://journal.iitta.gov.ua/index.php/itlt/ article/view/1666.

[5] Potapov, P. G. Problems of modern methodology: methods of Internet research. In Vysshee obrazovanie v Rossii i Belarusi v kontekste Bolonskogo processa, 308-311. Homel : HHTU ym. P. O. Sukhoho, 2016. https://elib. gstu.by/bitstream/handle/220612/14549.

[6] On Amendments to the Decree of the Cabinet of Ministers of Ukraine dated December 30, 2015. \# 1187. Postanova Kabinetu Ministriv Ukrainy vid 10.05.2018. № 347. http://zakon.rada.gov.ua/laws/show/3472018-\%D0\%BF. 